ISSN 0258-7122

Bangladesh J. Agril. Res. 37(1): 77-95, March 2012

\title{
PROFITABILITY OF FLOWER PRODUCTION AND MARKETING SYSTEM OF BANGLADESH*
}

\author{
NUSRAT HASAN MOU ${ }^{1}$
}

\begin{abstract}
This study examines the production and profitability of some selected flowers in comparison with their competing crops. The study also attempts to identify the value chains and channels of flower marketing in Bangladesh. Stratified random sampling method was used to collect Primary data collected from the 32 farmers of Guptergaon under Phulpur Upazila in Mymensingh district and from the 21 flower traders, retailers and wholesalers of different flower trading zones in Dhaka city. The study reveals that gross margins of flower and vegetables per hectare were Tk.1,359,824.20 and Tk.46,362.14, respectively. The average marketing margin of three intermediaries i.e., BRAC, wholesaler-cum-retailer and retailer in Dhaka city, were Tk. 187.56, Tk. 638.39 and Tk.689.72 per 100 flowers, respectively. Lack of mother stock and their high price, price of fertilizer and insecticides, lack of scientific knowledge $\&$ training, attack by pest $\&$ disease, lack of extension work came out as major financial and technical problems of the flower farmers while inadequate \& underdeveloped transportation \& communication system, low market price, lack of market information, unstructured market are among major market related problems. On the other hand marketing intermediaries specified price instability, lack of adequate market information, lacking storage facilities, unsold flower, inadequate shop-space, demand fluctuation, strikes as their problems and constraints. Pertinent recommendations for facilitating flower production and developing an improved marketing system in Bangladesh include - a concentrated effort by the government and non-govt. agencies to provide appropriate trainings to farmers and traders, to provide appropriate production assistance and storage facility \& to build countrywide permanent trading infrastructure, deployment of an Market Information System (MIS) and deployment of Entrepreneur-friendly SME and credit policies and packages for ensuring a balanced growth of the floriculture industry.
\end{abstract}

Keywords: Flower production in Bangladesh, flower marketing in Bangladesh, floriculture in Bangladesh, flower trading.

\section{Introduction}

The floral industry is one of the major industries in many developing and underdeveloped countries. Bangladesh is not an exception. In Bangladesh,

* This research was conducted as part of MS course curriculum of the author.

${ }^{1} \mathrm{MS}$ Student, Dept. of Agri. Economics, Bangladesh Agricultural University (BAU), Mymensingh, Bangladesh. 
floriculture brought into limelight by some innovative farmers in late seventies with tuberose on a small-scale basis. Large-scale commercial production started from mid eighties in Jhikargacha upazila of Jessore district (Sultana, 2003). Later it speeded largely in Jessore, Savar, Chuandanga, Mymensingh and Gazipur which turned to be the major flower production belt in Bangladesh.

Cultivation of flower is reported to give 3-5 times and 1.5-2 times more returns than obtained from rice and vegetable cultivation, respectively (Dadlani, 2003). At present, 10,000 hectares of land covers flower cultivation taking the lead by Jessore district. More than 5,000 resilient farmers are growing flower and foliage in the country and about 150,000 people are directly or indirectly involved in floriculture business as their sole livelihood (Chowdhury, 2010). Approximately 8,000 farmers are involved in flower cultivation and 2000 to 3000 farmers in ornamental plants on commercial basis. About 100,000 to 120,000 people are directly or indirectly involved in floriculture industry for their livelihoods. The area coverage under commercial flower cultivation is approximately 10,000 hectares of land while commercial nurseries have covered approximately 2,000 to 2,500 hectares of land (Momin, 2006).

At present, flower-marketing is not fully organized in Bangladesh. Major traders for flowers can be found in Shahbag, Farmgate and Gulshan in Dhaka. Substantial trade can also be found in Chittagong and other big cities. There are reportedly around 4000 retail shops of flowers in the country. Forty per cent of the retail shops are located in Dhaka, while Chittagong and Sylhet having 25 per cent each and the remaining 10 per cent of the shops are in other district towns. At a wholesale flower market (in Dhaka), some 700 traders do flower business worth at least $\$ 16,000$ every day. Every year Bangladesh exports a large amount of flower by different intermediaries in the world market, which include mainly cut flowers and ornamental foliage.

To satisfy the market demand, various flowers, such as chrysanthemum, tuberose, gladiolus have been imported from India and orchids, gerbera, anthurium and Thai rose from Thailand every year. Bangladesh has to spend roughly Tk. 2-3 million in importing flowers and ornamental plants from abroad.

Larger share of export receipts of cut flowers and ornamental foliage, live trees and plants by Bangladesh in 2009-2010 was from European countries, while larger share of import expenses for the same period was from China and Indonesia. Table 1a shows continent-wise export receipts (from FY 2003-04 to 2009-10) and Table 1b shows country-wise import expenses (from FY 2005-06 to 2009-10) of Cut Flowers and Ornamental Foliage, Live trees and Plants by Bangladesh. 
PROFITABILITY OF FLOWER PRODUCTION AND MARKETING

Table 1a. Continent-wise export receipts of cut flowers and ornamental foliage, live trees and plants of Bangladesh.

(Taka in thousands)

\begin{tabular}{lrrrrrrrr}
\hline \multicolumn{1}{c}{ Country/FY } & $2003-04$ & $2004-05$ & $2005-06$ & $2006-07$ & $2007-08$ & $2008-09$ & $2009-10$ & Total \\
\hline Africa & - & - & - & 12,843 & 210 & - & 178 & 13,231 \\
Asia & 78,591 & 133,698 & 234,446 & 458,686 & $1,060,066$ & $1,227,430$ & $1,217,577$ & $4,410,494$ \\
Australia & - & - & - & 463 & 1,676 & - & - & 2,139 \\
Europe & 270,912 & 360,912 & 542,157 & 951,017 & 802,897 & 755,652 & $3,037,514$ & $6,721,061$ \\
North America & 879 & 2,813 & 32,455 & 37,799 & - & 19,949 & 17,973 & 111,868 \\
South America & - & - & - & - & - & 787 & - & 787 \\
\hline Total & 350,382 & 497,423 & 809,058 & $1,460,808$ & $1,864,849$ & $2,003,818$ & $4,273,242$ & $11,259,580$ \\
\hline
\end{tabular}

Source: Annual Export Receipts 2003-04 to 2009-10, Statistics Department, Bangladesh Bank

Table 1b. Country-wise import Expense of cut flowers and ornamental foliage, live trees and plants of Bangladesh.

(Taka in thousands)

\begin{tabular}{lrrrrr}
\hline \multicolumn{1}{c}{ Country/FY } & $2005-06$ & $2006-07$ & $2007-08$ & $2008-09$ & $2009-10$ \\
\hline China, People's & 24 & 501 & 473 & 2378 & 7944 \\
Republic & 0 & 2737 & 0 & 0 & 0 \\
Germany & 0 & 7160 & 0 & 0 & 132 \\
Hong Kong & 857 & 1282 & 537 & 5762 & 5732 \\
India & 472 & 0 & 0 & 0 & 0 \\
Indonesia & 0 & 0 & 0 & 5142 & 0 \\
Japan & 0 & 0 & 0 & 0 & 1849 \\
Netherlands & 0 & 0 & 0 & 129 & 0 \\
Korea, Republic of & 0 & 0 & 0 & 4654 & 0 \\
Malaysia & 525 & 1348 & 644 & 3999 & 801 \\
Pakistan & 0 & 0 & 0 & 606 & 0 \\
Singapore & 2596 & 1116 & 2030 & 10587 & 2473 \\
Thailand & 0 & 2781 & 0 & 0 & 0 \\
UK & 0 & 0 & 0 & 0 & 125 \\
USA & 4474 & 16925 & 3684 & 33257 & 19056 \\
\hline Total & & & & & \\
\hline
\end{tabular}

Source: Annual Import Payments 2005-06 to 2009-10, Statistics Department, Bangladesh Bank 
A study by Hossain and Rahman (1994) reveals that the capital investment in flower business has been increasing, the total number of shop exhibits an increasing trend, merchandizing patterns have been diversified, the scale of flower made products is rising and all sales are for cash. The positive attitude of respondents toward flowers, multipurpose uses of flowers, increasing uses of flower made products and an unsatisfied demand of some flowers are all positive indicators of the business boom. Hassan (1996) showed producers, marketing intermediaries and traders secure significant profit from flower production and marketing.

However, Sultana (1995) identified some problems of flower marketing which are - unavailability of sufficient flowers according to demand at right time, spoilage, lack of adequate and suitable transportation system. She suggested some measures to overcome these problems such as establishment of modem storage facilities, improvement of cultivation practices of flower for the whole year and arrangement of contract marketing.

According to Export Promotion Bureau statistics, Bangladesh exported flower/foliage worth $\$ 17.33$ million in the first half of the current fiscal year with 9.20 percent growth over the same period last year. ${ }^{2}$ Growing export trend (Fig. 1) depicts that Bangladesh has a tremendous potential for flower-farming for both domestic and export market. Not only it can play a significant role in minimizing the Balance of Payments negativity by earning invaluable foreign exchange, but also it can have great socio-economic influence by generating substantial employment and entrepreneurship - both of which can contribute a major portion of Gross Domestic Product (GDP) of Bangladesh.

This study has been undertaken to determine the nature and characteristics and the impact of contract flower farming in flower production in Bangladesh which may help the stakeholders to have valuable insight of floriculture industry of Bangladesh and its development thereby. In doing so, this study attempts to estimate productivity and profitability of flower production versus its competing crops; to determine the value chain of flower market and to identify opportunities and constraints in production and marketing of flowers.

\section{Contract Farming}

'Contract Farming' is the agreement between farmers and processing and/or marketing firms for the production and supply of agricultural products under forward agreements, frequently at predetermined prices. The arrangement also invariably involves the purchaser in providing a degree of production support through, for example, the supply of inputs and the provision of technical advice.

\footnotetext{
${ }^{2}$ Feature Article "A month of florists" by Kawsar Khan (http://www.thedailystar.net/story.php?nid=127358);Published On: 22 Feb 2010
} 
The basis of such arrangements is a commitment on the part of the farmer to provide a specific commodity in quantities and at quality standards determined by the purchaser and a commitment on the part of the company to support the farmer's production and to purchase the commodity.

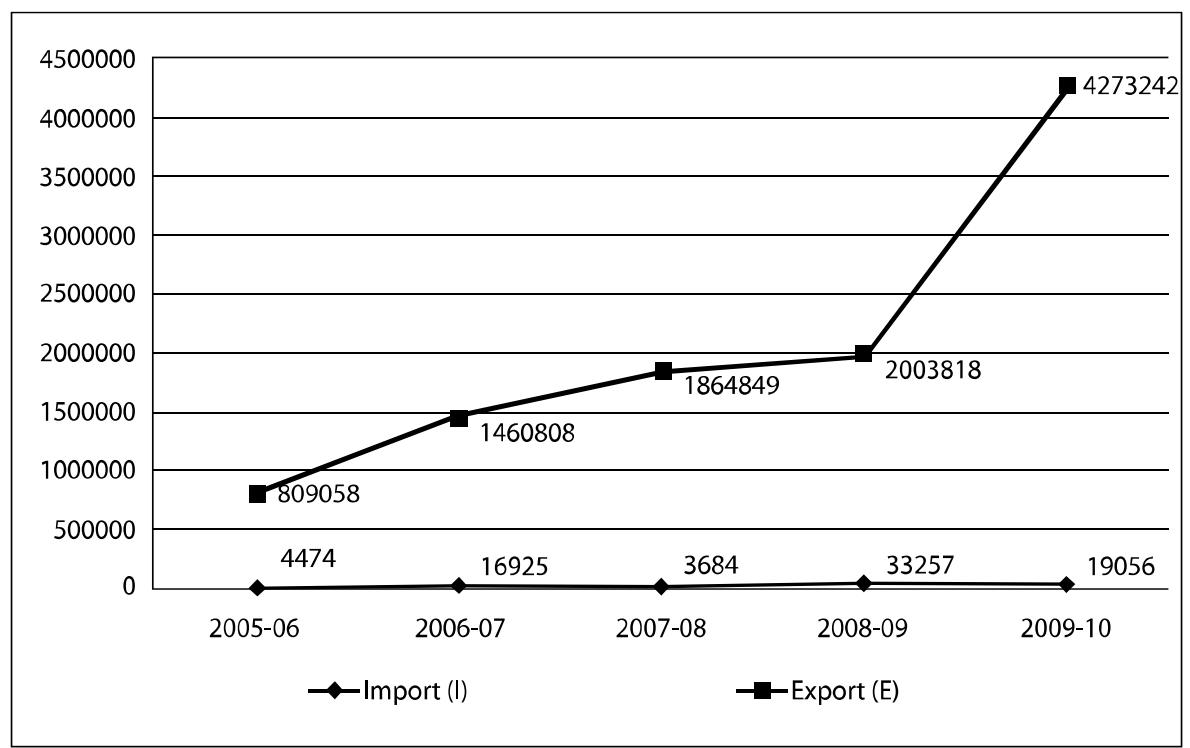

Figure 1. Export-import trend of cut flowers and ornamental foliage, live trees and plants of Bangladesh.

Source: Annual Import Payments 2005-06 to 2009-10, Statistics Department, Bangladesh Bank

Bangladesh Rural Advancement Committee (BRAC), one of the largest NGOs of the country, is the pioneer in commercial flower production and marketing in Bangladesh. As a result, BRAC launched its contract floriculture activity in November 2002 in Phulpur Upazila under Mymensingh District to produce flower for local and international market with the aim to bring about socio-economic improvements in rural Bangladesh as well as earn foreign currency for the country.

Although BRAC has introduced contract farming of vegetables and fruits for export a few years back, contract farming of flower is a new concept for BRAC as well as in Bangladesh. The aim is to make rural people a productive labor force and increase their employment through income generating capacities and opportunities. BRAC covered the cost of infrastructure, plants, inputs, training, regular follow up and post-harvest marketing opportunities leaving the rest upon farmers. Guaranteed fixed price for produced flowers acted as security against 
fluctuation in market price and encouraged farmers to put their best effort for maximizing return.

In Bangladesh, contract farming is a recent form of production organization, which integrates producers of high value farm product with the domestic as well as international marketing outlets (Mandal, 2004). Contracting system in Bangladesh developed after the creation of Crop Diversification Board (CDB). In 1975-76, CDB introduced the contract growing of cotton seed (Hossain and Rahman, 1994). Hasan (2005) conducted a study to characterize the contract farming for production and export of high value vegetables along with the profitability of contracts vis-à-vis non contract vegetable growers.

\section{The model of contract flower farming developed by BRAC}

The contract flower farming system developed in Bangladesh between the Bangladesh Rural Advancement Committee and the contract growers of Phulpur Upazilla is a combination of centralized and full management contract, which can be termed as "Centralized Full Management Contract". Fig. 2 shows BRAC model of centralized full management contract flower farming.

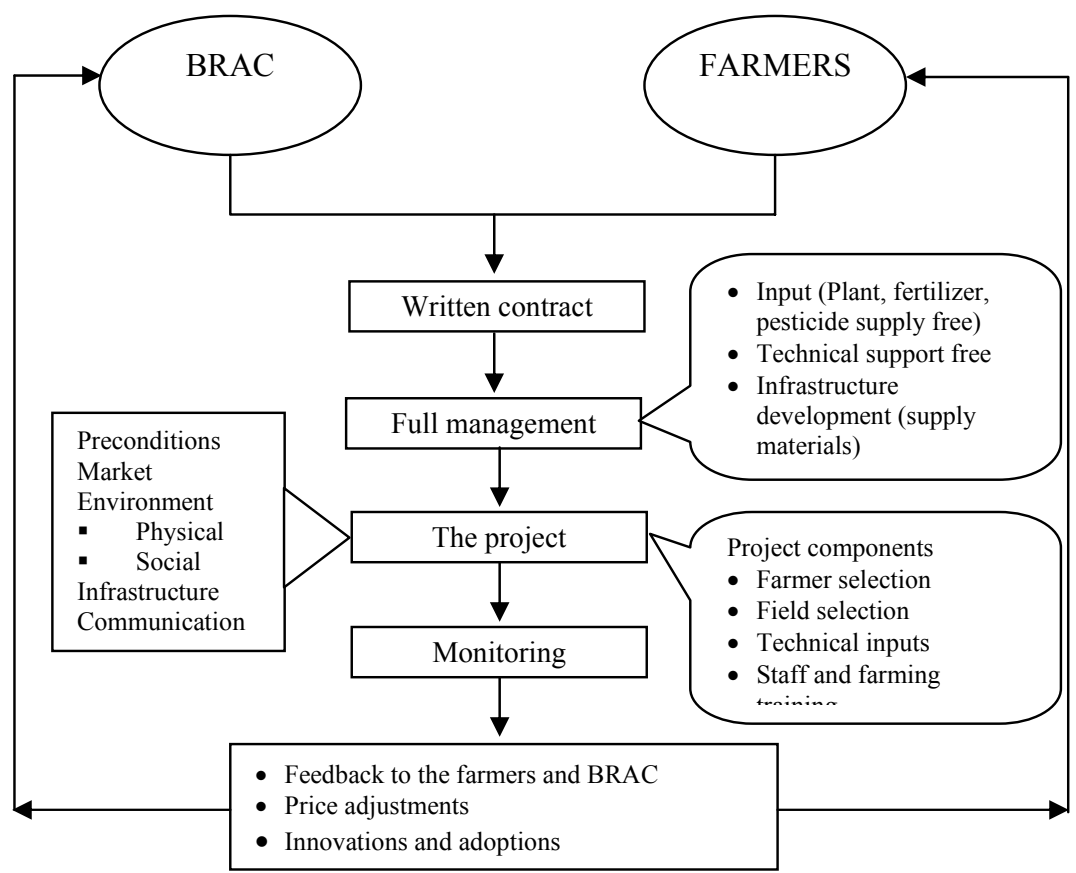

Fig. 2. BRAC Model of centralized full management contract flower farming 


\section{Methodology}

\section{Data collection}

Guptergaon under Phulpur Upazila in Mymensingh district was selected for the study because this area is the pioneer in the cultivation export quality flowers under contract farming through a pilot project of BRAC. Traders from Shahbag (the largest wholesale flower market in Dhaka), Farmgate (Khamar Bari), Mirpur and Gulshan area of Dhaka City were selected for getting information about the marketing system as these areas have defined market place for flower trading where flower farmers and traders from all over Bangladesh.

Primary data was collected through semi structured interviews with flower farmers using a structured survey questionnaire which was filled up by the interviewer. The questionnaire was tested before final survey was made with 5 farmers and 5 traders for appropriate amendments to improve it. A stratified random survey method was used to collect data from 32 farmers from the Guptergaon under Phulpur Upazila in Mymensingh district and 21 traders from different areas of the Dhaka City. Thus the total sample size was 53 which include flower farmers, retailers, wholesalers and retailer cum wholesalers. The present study covered six month period from July 2006 to December 2006. Data were collected during the period from August 2006 to October 2006 through direct interviews with the interviewers at their work site or homestead.

In addition to primary data secondary data were also collected from various sources. Some information was collected from the record books of BRAC. Besides, various books, journals, newspaper, documents of Bangladesh Bureau of Statistics (BBS), Department of Agricultural Economics of Bangladesh Agricultural University and related websites were consulted for appropriate secondary data.

\section{Data analysis}

Primary data was recorded into Microsoft Excel worksheet and economic analysis was carried out for determining costs and returns.

In this study, cost and return analyses were done on both variable and total cost basis. To achieve the objective of the study a simple tabular analysis was completed. The following profit equation was developed to assess the profitability of flower cultivation and vegetable cultivation.

$$
\Pi=\text { Gross return }-(\text { Variable cost }+ \text { Fixed cost })
$$

$$
\begin{array}{ll}
\text { Here, } \Pi & =\text { Profit per hectare } \\
\text { Gross return } & =\text { Total production } \times \text { per unit price }
\end{array}
$$


Variable costs,

i. Cost of seedling or plantlet

ii. Cost of human labor

iii. Cost of animal power

iv. Cost of power tiller

v. Cost of fertilizer

vi. Cost of irrigation

vii. Cost of insecticide
Fixed costs,

i. Family labor

ii. Family supplied animal power

iii. Land use cost

iv. Interest on operating capital

The separate activity analyses of farm producing different combination of flowers are also performed by tabular analysis. Per hectare profitability of flower cultivation from the view point of individual farmers was measured in terms of gross return, gross margin, net return and benefit cost ratio (undiscounted).

Assuming the null hypothesis that there is no significant difference between the profit of two sectors (Flower cultivation and vegetable cultivation) a t-test was done for finding the significance level justifying the hypothesis.

\section{Results and Discussion}

\section{Socioe-conomic characteristics of sample flower farmers}

Age and sex distribution and literacy status of the sample farmers: Considering the age of growers, majority of contract growers come from the age group between 30-40 years, indicating that the contract farmers were relatively younger and were early adopter to encourage the contract flower farming system $21.87 \%$ of the contract farmers were illiterate. Up to primary, secondary, higher secondary and above higher secondary education level the percentages are 15.63, $31.25,25.00$ and 6.25 respectively.

Occupational status of flower farmers: About 59.38 percent farm owners were engaged in flower farming with crop production, 3.12 percent in flower farming with service and business, 21.88 percent engaged in flower farming with crop production and business (Table 2 ).

Land ownership patterns of flower farmers: In this study the land size was measured by using the following formula: Land size: Own land (homestead + pond + garden + land under flower + Crop area $)+($ Rented in + Mortgaged in $)-$ (Rented out + mortgaged out). It appears from the table that in terms of land size, small and medium farmers accounted for three-fourths of all the flower farmers under BRAC management (Table 3). 
Table 2. Occupational distribution of flower farmer.

\begin{tabular}{l|rr}
\hline \multirow{2}{*}{\multicolumn{1}{c}{ Items }} & \multicolumn{2}{c}{ Farm owners } \\
\cline { 2 - 3 } & Number & (\%) \\
\hline Only Flower farming & 0 & 0 \\
Flower farming + crop farming & 19 & 59.38 \\
Flower farming + crop farming + business & 7 & 21.88 \\
Flower farming + business & 3 & 9.38 \\
Flower farming + service & 1 & 3.12 \\
Flower farming +crop production +service & 1 & 3.12 \\
Flower farming + business +service & 1 & 3.12 \\
Flower farming + housekeeping & 0 & 0 \\
\hline Total & 32 & 100 \\
\hline
\end{tabular}

Source: Field survey, 2006

Table 3. Average land area per farmer.

\begin{tabular}{|c|c|c|c|c|c|c|c|}
\hline \multirow{2}{*}{$\begin{array}{c}\text { Size of } \\
\text { land area } \\
\text { (decimals) }\end{array}$} & \multirow{2}{*}{$\begin{array}{l}\text { No. of } \\
\text { farmers }\end{array}$} & \multicolumn{6}{|c|}{$\begin{array}{l}\text { Average land area per farm in decimal } \\
\text { Figures in the parentheses indicate percentages of total land }\end{array}$} \\
\hline & & $\begin{array}{l}\text { Land } \\
\text { under } \\
\text { flower }\end{array}$ & Crop & Homestead & Pond & Garden & Total land \\
\hline $50-100$ & 4 & $8.75(12.6)$ & $\begin{array}{r}38.18 \\
(54.99)\end{array}$ & $\begin{array}{r}17.25 \\
(24.85)\end{array}$ & $3.25(4.68)$ & $2(2.88)$ & $69.43(100)$ \\
\hline $101-250$ & 16 & $8.53(5.26)$ & $\begin{array}{r}125.89 \\
(77.67)\end{array}$ & $\begin{array}{r}17.87 \\
(11.02)\end{array}$ & $3.40(2.1)$ & $6.4(3.95)$ & $\begin{array}{r}162.09 \\
(100)\end{array}$ \\
\hline $251-400$ & 8 & $\begin{array}{r}10.50 \\
(3.33)\end{array}$ & $\begin{array}{r}271.5 \\
(86.15)\end{array}$ & $16.13(5.11)$ & $\begin{array}{l}11.13 \\
(2.53)\end{array}$ & $\begin{array}{r}5.87 \\
(1.86)\end{array}$ & $\begin{array}{r}315.13 \\
(100)\end{array}$ \\
\hline $401-600$ & 4 & $\begin{array}{r}10.00 \\
(1.85)\end{array}$ & $\begin{array}{l}464.75 \\
(86.18)\end{array}$ & $32.38(6.00)$ & $\begin{array}{l}12.25 \\
(2.27)\end{array}$ & $20(3.71)$ & $\begin{array}{r}539.30 \\
(100)\end{array}$ \\
\hline
\end{tabular}

Source: Field survey, 2006

Annual income of farm families: In the present study, three sources of income such as agriculture, business and others were identified. The average annual income of farm was estimated at TK 165,521 of which 55\% came from agriculture, $23 \%$ from business and $22 \%$ from other professions and ventures (Table 4). 
Table 4. Sources of annual income of farm families.

\begin{tabular}{lrr}
\hline \multicolumn{1}{c|}{ Sources of income } & Annual income(Tk.) & Percentage \\
\hline Agriculture & 90,854 & 55 \\
Business & 38,667 & 23 \\
Other & 36,000 & 22 \\
\hline Average & 165,521 & 100 \\
\hline
\end{tabular}

Source: Field survey, 2006

Ownership pattern: Hundred percent of the sample farmers in the study areas controlled their farming by single ownership.

\section{Socio-economic characteristics of intermediaries}

The socio-economic characteristics which were taken into consideration to asses the socio-economic status of intermediaries were age, family size, level of literacy, occupation, ownership pattern and sources of funds.

Age and level of education of intermediaries: Most of the intermediaries were from 30-45 years age group there was no illiterate traders. Percentages of Primary, High School, Secondary, Higher Secondary and above education level were 5, 55, 20, 15 and 5, respectively.

Occupational distribution of flower intermediaries: Sixty percent and 53.3 percent of the wholesaler-cum-retailers and retailers respectively were involved in only flower trading whereas 20 percent of wholesaler-cum-retailers and 26.7 percent of retailers were involved in flower trading with other business. This study also reveals that 10 percent of the traders were college and university student

Ownership pattern of the intermediaries: Most of the flower intermediaries (85 percent) were single owners while about 15 percent of the flower traders were doing business jointly.

Sources of funds: Seventy five percent of the intermediaries started their business with their own funds and 3 percent of traders borrowed funds from noninstitutional sources i.e. friends and relatives. Only 2 percent of the intermediaries borrowed funds from institutional sources.

Productivity and profitability of flower production versus its competing crops: To identify profitability of flower production and compare the cost and return of flower and vegetables grown by same farmers, both net return on cash cost and net return on full cost are estimated. In the present study a number of variable and fixed costs were reported to have been incurred in flower production. 
Per hectare total cost or average total cost for producing flower was Tk. 18,82,201.44 and for vegetable per hectare average cost was Tk 99,742.50 (Table 5 ). The per hectare cost of production for contract flower farming was higher than vegetable cultivation, which might be due intensive use of the factors of production. Per hectare total cost of various combinations of flowers were Tk. 44,02,181.61, Tk. 7,90,628.79, Tk. 6,18,574.02 and Tk. 6,59,132.58 for orchid, gerbera + rose, gerbera + rose + gladiolus and gerbera cultivation respectively (Table 6).

Table 5. Cost and return of flower and vegetables.

\begin{tabular}{lrr}
\hline Particulars & Flower & Vegetables \\
\hline Yield & 721885.80 Piece & $10966 \mathrm{Kg}$ \\
Price/unit & $4.29 /$ piece & $10 / \mathrm{Kg}$ \\
Gross return & 3103372.32 & 109660.13 \\
Cash cost & 1730616.90 & 63297 \\
Total cost & $\mathbf{1 8 8 2 2 0 1 . 4 4}$ & $\mathbf{9 9 7 4 2 . 5 0}$ \\
Return over cash cost & 1359824.20 & 46362.14 \\
Net return on full cost & $\mathbf{1 2 2 1 1 7 0 . 8 8}$ & $\mathbf{9 9 1 7 . 6 3}$ \\
BCR (cash cost basis) & 1.77 & 1.73 \\
BCR (Total cost basis) & 1.65 & 1.09 \\
\hline
\end{tabular}

Source: Field survey, 2006

Return over cash cost of flower and vegetable were calculated by deducting total cash cost from the gross return. Per hectare return over cash cost of flower and vegetable production were Tk. 13,59,824.20 and 46,362.14 respectively. Net returns of flower and vegetable production were Tk. 12,21,170.88 and Tk. 9,917.63 respectively (Table 5). Gross Return were Tk. 4620876.00, Tk. 2600910.00, Tk. 1308671.87 and Tk. 3061976.67, Return Over Cash Cost were Tk. 4,28,988.6, Tk. 19,27,626.12, Tk. 8,01,332.88 and Tk. 25,33,078.03 and Net Return were Tk. 2,18,694.39, Tk. 18,10,281.21, Tk. 6,90,097.84 and Tk. $24,02,844.00$ for orchid, gerbera + rose, gerbera + rose + gladiolus and gerbera respectively (Table 6). 
Table 6. Return per hectare from selected flowers

\begin{tabular}{|c|c|c|c|c|}
\hline \multirow[b]{2}{*}{ Particulars } & \multicolumn{4}{|c|}{ Combination } \\
\hline & Orchid & $\begin{array}{c}\text { Gerbera and } \\
\text { rose }\end{array}$ & $\begin{array}{l}\text { Gerbera, rose } \\
\text { and gladiolus }\end{array}$ & Gerbera \\
\hline $\begin{array}{l}\text { Gross return } \\
\text { (Tk./ha) }\end{array}$ & 4620876.00 & 2600910.00 & 1308671.87 & 3061976.67 \\
\hline Total cost (Tk./ha) & 4402181.61 & 790628.79 & 618574.02 & 659132.58 \\
\hline Cash $\operatorname{cost}(\mathrm{Tk} / \mathrm{ha})$ & 4191887.4 & 673283.88 & 507338.99 & 528898.64 \\
\hline $\begin{array}{l}\text { Return over cash } \\
\text { cost }\end{array}$ & 428988.6 & 1927626.12 & 801332.88 & 2533078.03 \\
\hline $\begin{array}{l}\text { Net return } \\
\text { (Tk./ha) }\end{array}$ & 218694.39 & 1810281.21 & 690097.84 & 2402844 \\
\hline BCR(cash cost) & 1.10 & 3.86 & 2.57 & 5.79 \\
\hline BCR(full cost) & 1.04 & 3.29 & 2.12 & 4.65 \\
\hline
\end{tabular}

Source: Field survey, 2006

Fig. 3 shows the comparison between Gross Return and the Net Return from cultivating these combinations of flowers. Compare mean test (Z-test) reveals that profit from flower farming is higher than profit from vegetable production.

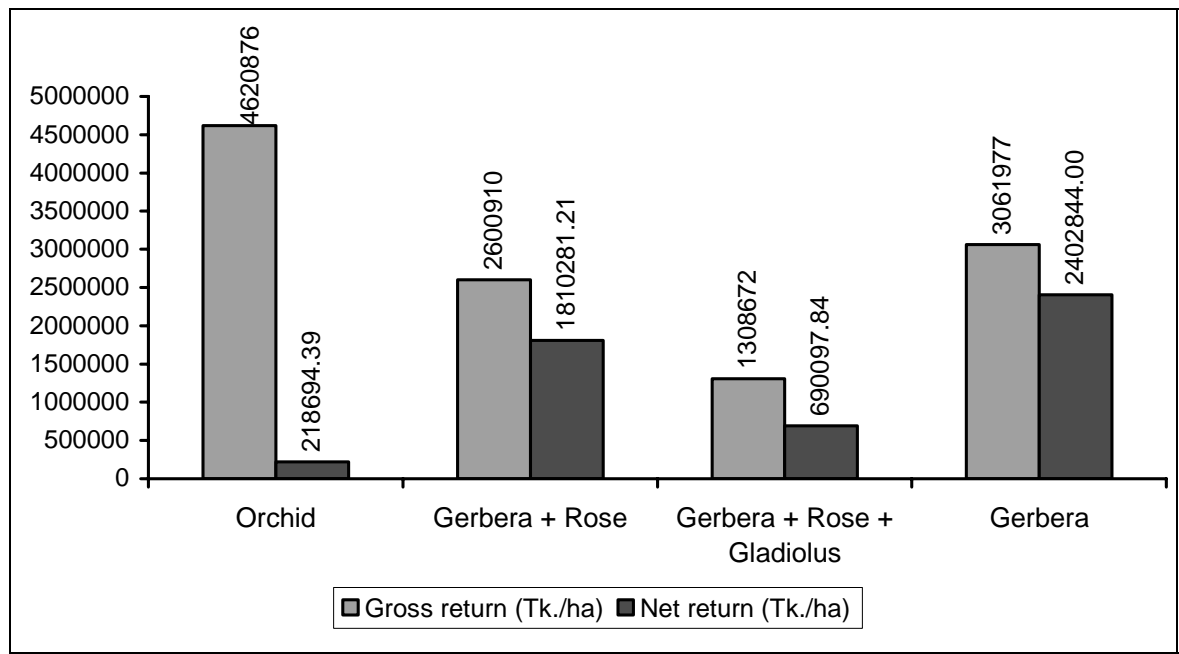

Fig. 3. Gross return and net return of different flowers practiced by the farmers.

The analysis clearly indicates that the per hectare production of flower are more profitable than vegetables. It implies that there is a bright prospect to earn more returns by using more inputs in the production process of flower. 
Marketing channels: Flower marketing channels in the study areas were small and simple. Figure 4 shows the three flower marketing channels identified in the study area.

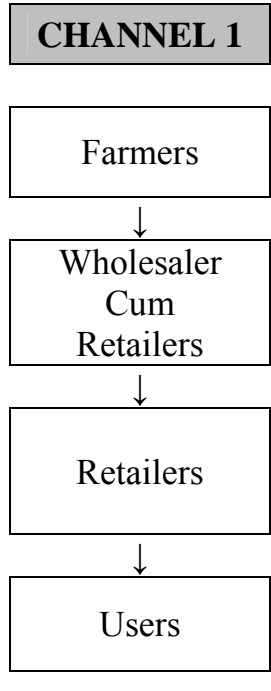

\section{Fig. 4. Flower Marketing Channels}

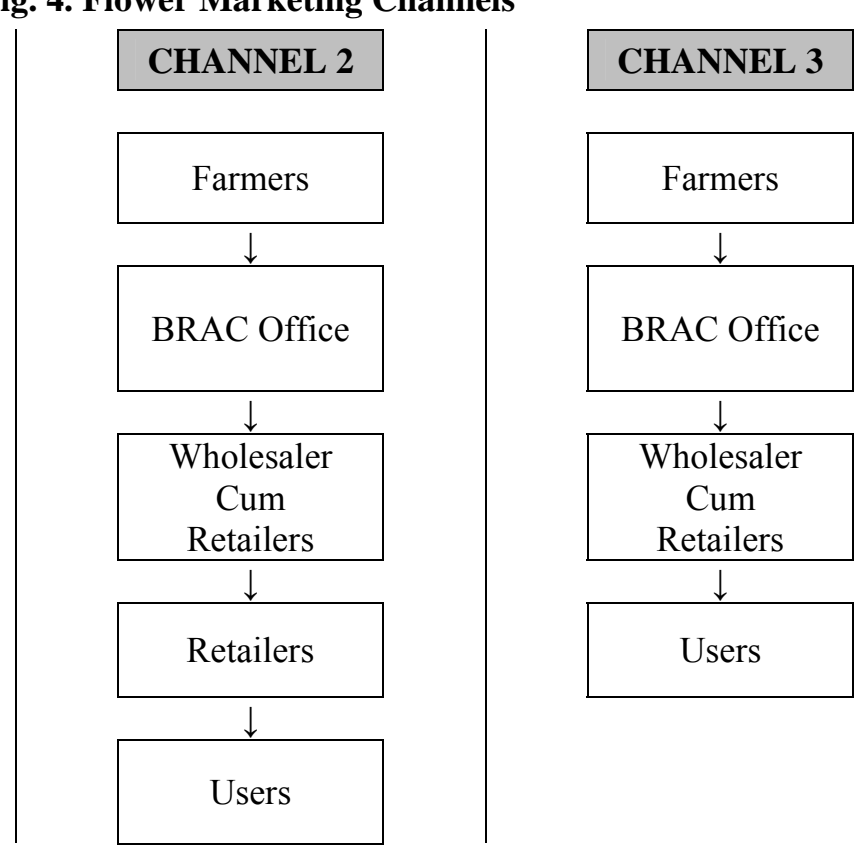

Majority (almost $80 \%$ ) of the produced flowers were channeled through BRAC Office (as shown in Channel $2 \& 3$ ) under contract farming agreements. Channel 1 shows the marketing channel of other farmers who were encouraged to grow some other types of flowers in their cultivable lands other than those in contract farming agreements.

In this study, the flower marketing value chain incorporates various marketing functions such as buying and selling, transportation, communication, storage, packing, grading, processing, financing, market information and promotion.

Volume handle: In this study on an average, BRAC (Phulpur), wholesaler cum retailers (Dhaka City), retailers (Dhaka City) handled respectively 1.5, 23 and 2.5 thousand of flowers per day. Wholesaler-cum-retailers handled highest amount, which was 85.11 percent followed by retailer (9.25\%) and BRAC (5.64 \%).

Transportation: In this study rickshaw, van, shoulder load, night coach and truck were the important means of transportation used by different intermediaries. Farmers transported most of their product by using shoulder load, 
rickshaw, van, by-cycle etc. to the BRAC center. Coach or bus was used for transporting flower from Phulpur to Dhaka City. The retailers at Shahbag area used rickshaw van to bring flowers to their shops. But at the time of home delivery of flowers and to furnish order various modes of transportation were used such as rental car, CNG auto, rickshaw, etc.

Packing: Flowers are packed in bundles and each bundle is comprised of 50 flower sticks. Then those bundles are placed within sack of transportation.

Grading: Farmers and traders of orchid, rose and gladiolus grades their flowers on the basis of size, color and defect. But gerbera and anthurium are graded according to size only.

Storage: The common practice is to allow the flowers to cool for a certain time after harvest to remove the field heat and thereafter these are packed. While packing, water is sprinkled to maintain high humidity. The traders used a crude method to preserve flowers in their shops. Usually the flowers, which have long stem such as orchid and gladiolus were kept in a bucket of water, placed in cool place and never exposed to sun. The water was changed after every twenty-four hours.

Processing: At present flowers are not mechanically processed but those are only changed in shape, size and form. The retailers sorted the flowers and arranged them in various alternative forms. Flowers were arranged according to the order of the buyer's preference and in the form of flower baskets, garlands, etc.

Marketing information: Most of the traders received their market information from market visit and personal interview and fellow traders. In the study area, BRAC and wholesaler-cum-retailer receive their information by telephone or mobile.

Promotion: Promotion received significant recognition from the flower traders. Forty per cent of shop owners used local newspaper followed by radio $(26.67 \%)$, TV $(20 \%)$ and the rest $(13.33 \%)$ national newspaper reported as media of advertisement.

Marketing cost of intermediaries: Marketing cost of flower intermediaries includes the expenses incurred by different intermediaries for movement of the flowers through the marketing channel. BRAC performed the functions of purchasing flowers from the farmer and transporting it to wholesaler-cum-retailers in Dhaka City. Wholesaler-cum-retailers performed the functions of purchasing flowers from BRAC or farmers and sold those to retailers and sometimes to users. BRAC accredited one wholesaler who purchased all the flowers from BRAC and supplied those to the retail shop according to order 
received for these. The retailers were involved in the functions of purchasing flowers from wholesaler-cum-retailers and selling it to the users.

Average marketing cost of BRAC, wholesaler-cum-retailer and retailer were Tk 12.44, 11.61 and Tk 50.28 for hundred flowers. Total marketing cost was Tk 74.33 for hundred flowers. Retailer share was $67.64 \%$ of the total cost. While BRAC and wholesaler cum retailer incurred Tk.16.74 and 15.62 respectively. Net marketing margin of BRAC, wholesaler-cum-retailer and retailer were Tk.187.56, Tk.628.39 and Tk.689.72 for 100 flowers respectively. Marketing margin was higher for retailer than wholesaler-cum-retailer than BRAC. Return on investment of wholesaler-cum-retailer was higher than other traders (Table 7).

Table 7. Price paid by intermediaries for the selected flowers.

\begin{tabular}{l|c|c|c|c}
\hline \multirow{2}{*}{$\begin{array}{c}\text { Name of the selected } \\
\text { flowers Type of } \\
\text { intermediaries }\end{array}$} & \multicolumn{4}{|c}{ Purchase price per stick flower in Taka } \\
\cline { 2 - 5 } & Orchid & Gerbera & Anthurium & Gladiolus \\
\hline BRAC & 3 & 2 & 2 & 2 \\
Wholesaler-cum-retailer & 6 & 4 & 4 & 4 \\
Retailer & 15 & 12 & 15 & 7 \\
User & 22 & 20 & 30 & 12 \\
\hline
\end{tabular}

Source: Field survey, 2006

\section{Production and marketing problems of farmers and intermediaries}

Production problem faced by flower farmers: For the sake of convenience the problems and constraints faced by the selected flower farmers in the study area have been categorized under four general groups such as economic, technical, marketing and social and other (Table 8). Considering the production problems faced by the farmers, the following measures were advocated by them -

- Development of scientific knowledge and modern technology for flower cultivation.

- Ensuring supply of quality seeds or plants for flower production.

- Co-operative marketing societies should be organized.

- Marketing information should be made available to the farmers through national mass media such as radio, television, newspaper, etc. 
Table 8. Problems faced by the farmers in producing flower.

\begin{tabular}{c|c|c}
\hline Problems & $\begin{array}{c}\text { No of respondents } \\
(\mathrm{n}=32)\end{array}$ & Percentage \\
\hline
\end{tabular}

\section{Economic problems}

Lack of mother stock and high price

High price of fertilizer and insecticides

\section{Technical problems}

Lack of scientific knowledge and training

Environment

Attack by pest and disease

Lack of extension work

\section{Marketing problems}

Inadequate and underdeveloped

transportation and communication system

Low market price

Lack of market information

78

\section{Social and other problems}

Loss of production due to thief 13

Flower damage by animals

Spoilage

Source: Field survey, 2006

Problem faced by intermediaries: In the study areas, the flower traders faced various problems. The problems as reported by them are presented in Table 9. In order to solve the marketing problems faced by the intermediaries the following measures were suggested.

- Institutional credit should be made available to the intermediaries on easy terms and at a lower rate of interest.

- Marketing loss should be reduced by improving storage, handling and processing facilities. Government should arrange training for flowers traders on post harvesting handling and storage of flowers on scientific basis.

- Market facilities, such as pucca floor, tin shed, drainage, etc. should be improved. 
Table 9. Problem faced by intermediaries.

\begin{tabular}{lc|c}
\hline \multicolumn{1}{c}{ Problems } & No. of traders $(\mathrm{n}=20)$ & $\%$ \\
\hline Price instability & 12 & 60 \\
Lack of adequate market information & 10 & 50 \\
Lack of storage facilities & 15 & 75 \\
Unsold flower & 18 & 90 \\
Inadequate space within the shop & 8 & 40 \\
Fluctuation of demand & 12 & 60 \\
Strike & 14 & 70 \\
\hline
\end{tabular}

Source: Field survey, 2006

\section{Conclusion}

This study finds that flower-farming shows encouraging results to improve farmer's socioeconomic condition, increases self-employment opportunity, promotes entrepreneurship in both urban and rural areas and boosts export-trade to earn foreign currency, it proves to be a potential tool for poverty alleviation and sustainable growth in the economy of Bangladesh. Specifically findings from the study are as below:

(a) Flower Farmers under "Centralized Full Management Contract" farming system of Bangladesh Rural Advancement Committee (BRAC) produce good quality flowers for both local and international market,

(b) Flower farming generates more revenue (almost double) than is cultivation of vegetables per hectare,

(c) Marketing margin is higher for retailer than wholesaler-cum-retailer than BRAC and Return on investment of wholesaler-cum-retailer was higher than other traders,

(d) Lack of mother stock and their high price, price of fertilizer and insecticides, lack of scientific knowledge \& training, attack by pest and disease, lack of extension work came out as major financial and technical problems of the flower farmer,

(e) Inadequate and underdeveloped transportation and communication system, low market price, lack of market information, unstructured market are among major market and marketing related problem,

(f) Marketing intermediaries specified price instability, lack of adequate market information, lacking storage facilities, unsold flower, inadequate shop-space, demand fluctuation, strikes as their problems and constraints. 
Despite the problems and constraints identified by this study, huge domestic profit margins in flower production and marketing has clear indication that, if properly nurtured, Bangladesh has tremendous potential to claim a better share of the pie of global floricultural trade which is a huge industry today. Based on the findings of the study, some recommendations for facilitating flower production and developing an improved marketing system in Bangladesh are as follows:

I. Government and non-Govt. agencies should take a concentrated effort -

a. to enhance flower production by train-up the flower-farmers,

b. to provide appropriate production assistance and storage facility,

c. to provide support farmers in marketing of the produced flowers,

d. to train and assist the traders in processing, grading, storing and displaying flowers, and

e. to allocate permanent market infrastructure in major cities for the selfgoverned flower markets in Dhaka and other major cities for facilitating flower trading.

II. A Market Information System (MIS) should be developed for ease access of the stakeholders to required updates of the industry.

III. Entrepreneur-friendly SME and credit policies and packages should be developed to ensure a balanced growth of the floriculture industry.

\section{References}

Annual Export Receipts 2006-2007 to 2009-2010, Statistics Department of Bangladesh Bank

Chowdhury, S. Z., 2010. Produce more fruits and vegetables instead of rice. The Daily Independent, February 11, 2010, Dhaka.

Dadlani, N.K. 2003. Global Positioning of Bangladesh Floriculture. A paper presented in International Floriculture Conference on $6^{\text {th }}$ November 2003, BARC, Farmgate, Dhaka.

Hasan M. R. 2005. An economic analysis of contract farming for production and export of high value vegetables in Bangladesh. Unpublished M.S Thesis, Department of Agricultural Economics, Bangladesh Agricultural University, Mymensingh.

Hassan, M. (1996). A Study on Production and Marketing of Tuberose in Some Selected Areas of Bangladesh. An M.S. Thesis, Department of Cooperation and Marketing, Bangladesh Agricultural University, Mymensingh. Bangladesh.

Hossain, M.B. and M.M. Rahman. 1994. The Potential of Flower Marketing in Dhaka City. Bureau of Business Research, University of Dhaka, Bangladesh.

Mandal, M.A.S. 2004. Contract Farming for High Value Enterprises, An article excerpted from the internet. 
Momin, M. A. 2006. Floriculture Survey in Bangladesh. A Consultancy Report, FAO. UNDP. (IHNDP/BGD/97/06)

Sultana, N. 1995. A Study on Flower Marketing in Dhaka City. An M.S. Thesis, Department of Co-operation

and Marketing, Bangladesh Agricultural University, Mymensingh. Bangladesh.

Sultana, N. 2003. Floriculture exports from Bangladesh. A paper presented in International Floriculture Conference on $6^{\text {th }}$ November, 2003, BARC, Farmgate, Dhaka. 